\title{
Long-term ice phenology records from eastern-central Europe
}

\author{
Katalin Takács ${ }^{1}$, Zoltán Kern ${ }^{2}$, and László Pásztor ${ }^{1}$ \\ ${ }^{1}$ Institute for Soil Sciences and Agricultural Chemistry, MTA Centre for Agricultural Research, \\ Herman Ottó 15, Budapest, 1022, Hungary \\ ${ }^{2}$ Institute for Geological and Geochemical Research, MTA Research Centre for Astronomy and Earth Sciences, \\ Budaörsi 45, Budapest, 1112, Hungary
}

Correspondence: Katalin Takács (takacs.katalin@ rissac.hu) and Zoltán Kern (kern.zoltan@csfk.mta.hu)

Received: 16 October 2017 - Discussion started: 6 November 2017

Revised: 6 November 2017 - Accepted: 1 February 2018 - Published: 7 March 2018

\begin{abstract}
A dataset of annual freshwater ice phenology was compiled for the largest river (Danube) and the largest lake (Lake Balaton) in eastern-central Europe, extending regular river and lake ice monitoring data through the use of historical observations and documentary records dating back to AD 1774 and AD 1885, respectively. What becomes clear is that the dates of the first appearance of ice and freeze-up have shifted, arriving $12-30$ and 4-13 days later, respectively, per 100 years. Break-up and ice-off have shifted to earlier dates by 7-13 and 9-27 days/100 years, except on Lake Balaton, where the date of break-up has not changed significantly. The datasets represent a resource for (paleo)climatological research thanks to the strong, physically determined link between water and air temperature and the occurrence of freshwater ice phenomena. The derived centennial records of freshwater cryophenology for the Danube and Balaton are readily available for detailed analysis of the temporal trends, large-scale spatial comparison, or other climatological purposes. The derived dataset is publicly available via PANGAEA at https://doi.org/10.1594/PANGAEA.881056.
\end{abstract}

\section{Introduction}

Freshwater ice is a major component of the terrestrial cryosphere (Brooks et al., 2013). At higher latitudes, mostly in the cold and temperate climate zones, many rivers and lakes are covered partly or fully by ice during the winter or even in autumn and spring (Beltaos and Prowse, 2009; Jensen et al., 2007; Weyhenmeyer et al., 2011). Seasonal ice cover can occur on rivers and lakes as far south as $33^{\circ} \mathrm{N}$ in North America and $26^{\circ} \mathrm{N}$ in Eurasia. Therefore, several large rivers and lakes from the world's top 15 - numbers 7 and 11 in the ranking - are affected (Prowse et al., 2007a). Although freshwater ice is characterized by pronounced seasonal variability compared to the other components of the cryosphere, it has a broad ecological and economic significance (Prowse et al., 2006, 2007a). For instance, river ice dynamics remarkably influences riparian and aquatic vegetation (Lind et al., 2014).

The timing and duration of the occurrence of ice phenomena are sensitive to winter weather conditions, especially to air temperature (Prowse et al., 2007b; Smith, 2000), making ice phenology data a good indicator of long-term climate change and inter-annual variability (Klavins et al., 2009; Sharma et al., 2016). There is great potential for climatic research in the analysis of long-term freshwater ice observations because direct information on climate properties can be provided not only about recent trends, but also about the temperature regimes even before the start of instrumental temperature observations (Klavins et al., 2009; Magnuson et al., 1999; Sharma et al., 2016). Despite observations of freshwater ice phenomena having a long history (Fujiwhara, 1921; Liljequist, 1941) and freshwater ice conditions having been collected routinely at a large number of water bodies, only a few stations have continuous ice phenology data series covering more than 100 years (Prowse et al., 2007b). The best-known long-term river and lake ice datasets are available for Tornionjoki (Finland) and Lake Suwa (Japan), with records going back 320 and 570 years, respectively 
(Sharma et al., 2016). The potential of long-term freshwater ice observations in (paleo)climatological research was recognized more than 40 years ago (Gray, 1974; Williams, 1970). Freeze-up records of Lake Suwa were among the few proxy records used in the first quantitative reconstruction of Northern Hemisphere annual mean temperatures (Groveman and Landsberg, 1979).

Owing to the long tradition of ice observations in Hungary, some relatively long ( $>240$ years) freshwater ice phenology datasets are available for eastern-central Europe as well. These are also suitable in the detection of long-term trends and climate change research. Here we present ice phenology data for the largest river (Danube) and the largest lake (Lake Balaton) of eastern-central Europe by combining historical periodical observations, documentary evidence, and regular river and lake ice monitoring data with daily records of freshwater ice observation from the 18th century to the present. This resulted in the longest river and lake ice regime dataset for eastern-central Europe.

\section{Data description}

\subsection{Ice phenology data}

Freshwater ice occurs in many forms on rivers and lakes. There are particular differences between the process of ice evolution on lakes, with static ice formation, and rivers, which are dynamic in terms of ice formation (Barry and Gan, 2011). However, the common point is that, after the water cools to below $0{ }^{\circ} \mathrm{C}$, frazil ice can develop. The other ice forms are then built up from frazil ice particles (Carlson, 1981). The regular freshwater ice observations include the monitoring of the following ice phenomena.

1. Border ice: ice attached to the shores along shallow river banks (Hicks, 2009) or adjacent to the lakeshore (Barry and Gan, 2011). At certain places border ice zones can merge, forming ice bridges.

2. Floating ice: on rivers the floating frazil ice built up to ice pans on the surface of the water by collisions; these forms are also known as pancake ice (Hicks, 2009). The form of ice occurring during ice cover break-ups can, in certain cases, also be called ice floes. Floating ice can be formed on lakes as well, when the amalgamation of surface ice pans and the direct development of ice cover are hindered by wind and waves (Barry and Gan, 2011).

3. Ice cover: on rivers, when floating ice covers more than $80-90 \%$ of the surface in the profile, ice pans can be pushed and frozen together to form a solid ice cover (Hicks, 2009). On lakes, in still conditions, ice cover can develop directly from frazil ice (Barry and Gan, 2011).

The ice regimes of rivers and lakes can be characterized by the dates of appearance and disappearance, duration, and frequency of the different ice phenomena during the winter seasons (Leppäranta, 2010; Smith, 2000). The following ice phenology records were extracted for each winter.

1. Ice-on: the start date of the first occurrence of floating ice

2. Freeze-up: the start date of the occurrence of continuous, solid ice cover

3. Break-up: when ice cover cracks and begins to float again, i.e., the date following the last ice-covered day

4. Ice-off: the date of ice disappearance, the date after the last day when floating ice (or ice floe) is present

5. Duration of ice cover: the number of days when ice cover occurred; and

6. Duration of the ice-affected season: the number of days when floating ice or ice cover occurred

\subsection{Data sources}

There are few stations around the Globe with records of freshwater ice phenology reaching back more than 100 years (Prowse et al., 2007b). However, in Hungary lake/river ice has traditionally been observed for more than 140 years. In eastern-central Europe knowledge of river and lake ice regimes has been important in relation to fishing, transportation (navigation and crossing possibilities of rivers and lakes), or river ice jam floods (Herman, 1887; Lukács, 1934; Rácz, 2016).

There are three major sources of freshwater ice phenology:

1. regular monitoring;

2. historical observations: relating to shorter periods;

3. documentary sources.

\subsubsection{Regular monitoring}

In Hungary, regular, daily observations started in 1876, simultaneously with construction and installation of the water level monitoring network (VITUKI, 1974). In the beginning, monitoring only included ice cover; no records were kept of floating ice (Lászlóffy, 1934). In this study, four stations were selected along the Danube which had been active since the beginning of regular ice observations: Komárom, Nagymaros, Budapest, and Mohács (VITUKI, 1974; Fig. 1). Regular ice monitoring at Lake Balaton began only in 1925, at Siófok (Fig. 1), and a network later developed with the addition of other stations (Baranyi, 1975). Sporadic observations of the ice phenology of Lake Balaton were also available from the Hydrographic Yearbooks dating back to 1885 .

From 1876, a summary of freshwater ice observation data was published together with daily water level records in the 


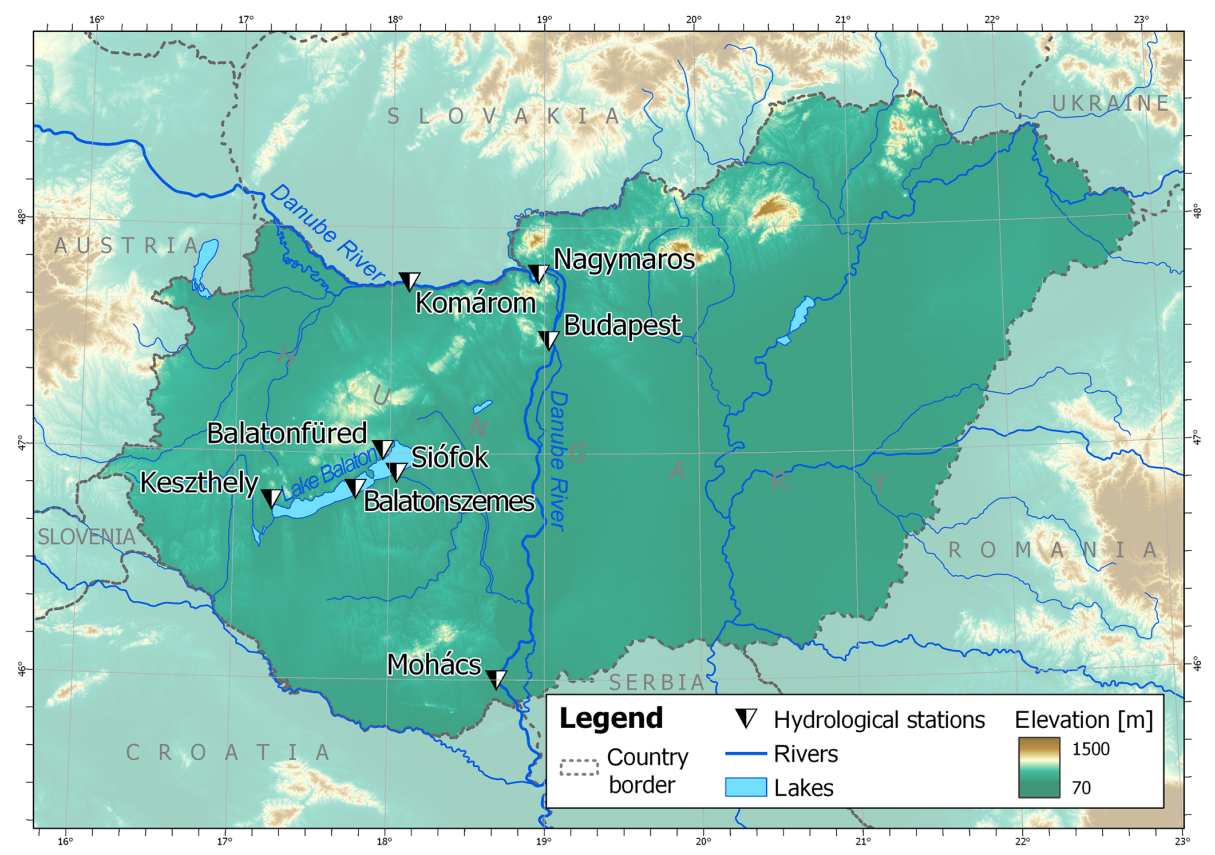

Figure 1. Locations of the hydrological stations mentioned in this study.

Table 1. Additional data sources concerning the ice regime of the River Danube and Lake Balaton.

\begin{tabular}{|c|c|c|}
\hline Water body & Period & Reference \\
\hline River Danube & $1847-1850$ & Arenstein (1850) \\
\hline River Danube & $1851-1861$ & Fritsch (1864) \\
\hline River Danube & $1860-1862$ & Fritsch (1867) \\
\hline River Danube & $1817-1932$ & $\begin{array}{l}\text { Kuzmann (1981), } \\
\text { Lászlóffy (1934) }\end{array}$ \\
\hline Lake Balaton & 1892-1904 & $\begin{array}{l}\text { Cholnoky (1907), } \\
\text { Sáringer (1900) }\end{array}$ \\
\hline Lake Balaton & 1920-1934 & Lukács (1934) \\
\hline
\end{tabular}

Hydrographic Yearbooks. Freshwater ice phenomena were recorded on a daily basis (i.e., day-month-year) and the defining criteria of the different freshwater ice phenomena remained common and consistent through the entire monitoring period, so the dataset is homogenous from a methodological point of view (Assel and Herche, 1998) and is characterized by a high degree of precision in its temporal resolution. Recent observations (from 2000) and digitized former records are available from the Hungarian Hydrological Database (MAHAB; Klausz and Pászthory, 2001). Data collection focusing on river ice observations for 1900-1970 has also been published in a separate book including processed data for 117 stations on several different rivers (VITUKI, 1974).

\subsubsection{Historical observations}

Historical freshwater ice observations relating to shorter periods are available for the Danube and Lake Balaton as well. These records are suitable for extending the existing time series of observations back to a date preceding the beginning of regular river and lake ice monitoring. Periodical observations were gathered and digitized to complete the time series of regular freshwater ice observations on the Danube River and Lake Balaton (Table 1). Although historical observations have not been made at the same place on the lake shore (Fig. 1), it was demonstrated that when multiple observation records were compared around the lake, no significant difference could be found in the ice regimes recorded at different places around Lake Balaton (Starosolszky, 1988). Stacking resulted in the longest time series of the lake ice regime for Balaton. Hereafter the stacked record of Lake Balaton will be referred to as "Balaton".

\subsubsection{Documentary sources}

From the 16 and 17th centuries several written sources relate to freshwater ice phenomena, although systematic observations from that period are not available (Vadas, 2013). Based on the collection on natural disasters and calamities in the historical area of Hungary (Réthly, 1970; Réthly and Simon, 1998, 1999), some information about freshwater ice regimes may be gathered. The validity and accuracy of the 19th century ice phenomena records are supported by the excellent correspondence between the seasonal removal and reestablishment of the pontoon bridge regularly used before the 
construction of the first stone bridge in the Hungarian capital (Rácz, 2016).

The long-term dataset of freshwater ice observations was compiled based on the above-mentioned data sources for the following periods:

1. River Danube: Komárom 1876-2017, Nagymaros 1876-2017, Budapest 1774-2017, Mohács 1876-2017;

2. Lake Balaton: 1885-2017.

\subsection{Data pre-processing}

For statistical evaluation and long-term trend detection, the raw version of freshwater ice phenology records underwent some pre-processing.

1. The calendar dates of ice phenomena appearances and disappearances were converted to numbers: 1 November was designated as 1 and the other dates were assigned numbers up to 160 , that is, 10 April.

2. Because of the climatic conditions of the investigated area, ice phenomena can appear and disappear more than one time in the course of the same winter. The first appearances (ice-on and freeze-up) and final disappearances (break-up and ice-off) were therefore selected from the station records for further analysis.

3. The durations of the ice-covered and ice-affected seasons were calculated taking into account the mid-winter break-up or ice-free periods.

4. A separate analysis was carried out of winter records in which no ice phenomena were observed.

\subsection{Analysis of the long-term trends in the eastern-central European freshwater ice phenology records}

We investigated the freshwater ice time series for the Danube and Lake Balaton for a long-term, linear trend. We applied two methods:

1. linear regression, a parametric method for trend testing in which the trend magnitude can be estimated from the regression slope, and

2. a non-parametric alternative for trend testing, the Mann-Kendall test (Kendall, 1975; Mann, 1945), in which the trend magnitude may be calculated with the use of the Sen slope estimator (Sen, 1968).

The advantage of the second method is that it is not sensitive to missing values. Trend estimations are related to the period 1885-2017 in Sect. 4.1 and 4.2 below. In all cases, the magnitude of trend was expressed in days/100 years. A positive trend means that the date of ice phenomena appearance/disappearance has shifted to later dates, or the duration of ice phenomena has increased, while a negative trend indicates the earlier appearance/disappearance of ice phenomena, or the decreasing duration of ice phenomena.

\section{Characteristics of the ice phenology}

Descriptive statistics of ice phenology records were compared for the longest common period (1885-2017) when freshwater ice observations for all stations were available (Fig. 2). The longest observation dataset (of the River Danube at Budapest) was also tested to investigate the differences and changes in the occurrence of ice phenomena compared to the shorter, recent period.

\subsection{The River Danube}

Ice occurrence is in general to be expected between late December and late February; ice cover usually builds up from mid-January to mid-February over the investigated section of the Danube, but in extreme cases these dates can vary as far as covering the period from November to March (Fig. 2, Table 2). On the basis of the observations, the earliest date of ice-on was 14 November 1888, and the latest date of ice-on was 26 February 1986. The earliest and latest freeze-up times were recorded on 9 December 1925 and 21 February 1887, respectively. In the case of break-up, the earliest date was 20 December 1902, while the latest was 26 March 1895. The earliest observed ice-off date was 30 November 1915, while the latest was 28 March 1940. In the case of the extended observations from Budapest, the mean and extreme dates are similar; earlier ice-on and freeze-up were only recorded on 11 November 1876 and 7 December 1774, respectively.

Considering the entire section of the Danube, ice-on occurs earlier at the upper stations because of the ice-drifting arriving from upstream. However, freeze-up starts at the lower sites and then the ice cover is built up in an upstream direction. Break-up also occurs earlier in the direction of flow, while ice-off takes place later on the lower sites (Fig. 2). There is an apparent contradiction between the mean dates of break-up and ice-off, so that the break-up occurs later than the ice-off on average. The explanation for this odd feature is the presence of winters with no ice cover at all (only drift ice appears). If ice cover is formed, the date of ice-off is to be found much later compared to years without any ice cover formation (Table 3).

The interannual variability of ice phenomena based on the standard deviation of the dates for the appearance of ice phenomena and their disappearance are similar at all of the observation sites along the investigated section of the Danube. In the case of ice-on and freeze-up, this is 15-21 days, while for break-up and ice-off it is somewhat higher, 20-25 days.

Over the investigated section of the Danube, the length of the ice-affected season - excluding the ice-free winters - is 

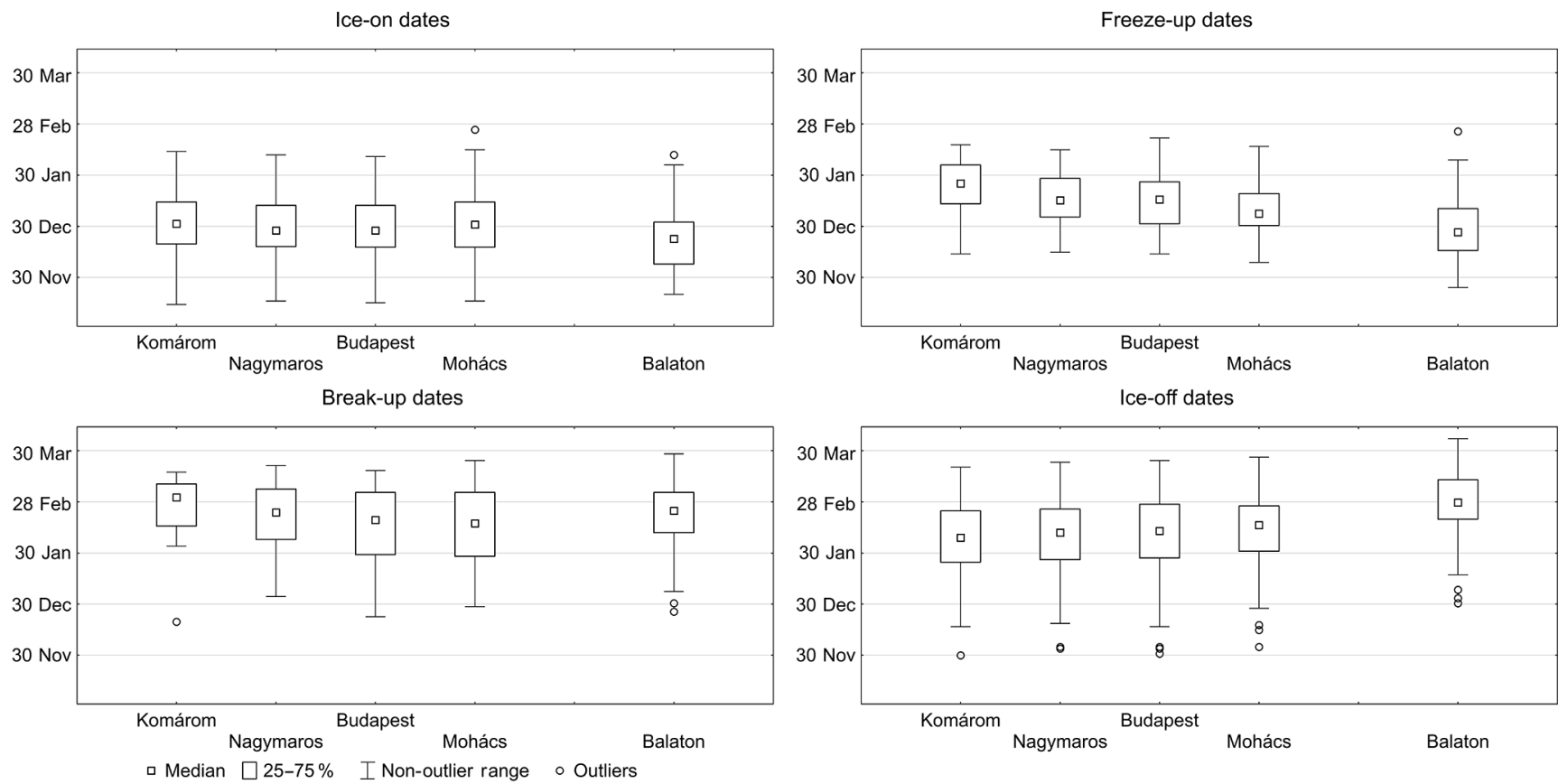

Figure 2. Basic characteristics of the ice regime of the River Danube and Lake Balaton from 1885 to 2017.

Table 2. Earliest, mean, and latest dates of the studied ice phenomena on the Danube and Lake Balaton recorded between 1885 and 2017.

\begin{tabular}{lllll}
\hline & & Earliest date & Mean date & Latest date \\
\hline Danube & ice-on & 14 November & 30 December & 26 February \\
& $\begin{array}{l}\text { freeze-up } \\
\text { break-up }\end{array}$ & 9 December & 14 January & 21 February \\
& ice-off & 30 November & 19 February & 26 March \\
\hline \multirow{2}{*}{ Balaton } & ice-on & 20 November & 23 December & 28 March \\
& 11 February \\
& breeze-up & 24 November & 30 December & 25 February \\
& 26 December & 21 February & 30 March \\
ice-off & 31 December & 28 February & 8 April \\
\hline
\end{tabular}

26-35 days on average, which increases in the direction of flow (Fig. 3). The longest ice-affected season was observed in 1894/1895, when 100 days of ice phenomena were recorded. The duration of ice cover is 29-36 days on average (omitting winters without ice cover), which also leads to an apparent contradiction (Fig. 3). Here, the explanation is similar, with the shift in mean statistics being caused by the presence of ice-cover-free winters, when the duration of the iceaffected season is much shorter than when ice cover develops as well. The longest duration of ice cover was recorded in 1946/1947, when ice cover lasted for 83 days. The extended historical observation dataset of Budapest contains only one longer record, in 1829/1830, when the ice cover lasted for 99 days. The interannual variability of the ice-covered and ice-affected seasons is $20-23$ and $22-28$ days, respectively.
Table 3. Comparison of break-up and ice-off dates relating to the whole dataset (whole) and winter with ice cover (ice cover) on the Danube and Lake Balaton from 1885 to 2017.

\begin{tabular}{llll}
\hline Station & Break-up & $\begin{array}{l}\text { Ice-off } \\
\text { (whole) }\end{array}$ & $\begin{array}{l}\text { Ice-off } \\
\text { (ice cover) }\end{array}$ \\
\hline Komárom & 24 February & 7 February & 2 March \\
Nagymaros & 21 February & 9 February & 1 March \\
Budapest & 14 February & 9 February & 27 February \\
Mohács & 15 February & 13 February & 26 February \\
Balaton & 21 February & 28 February & 28 February \\
\hline
\end{tabular}

\subsection{Lake Balaton}

Ice-on and freeze-up can occur as early as late December on Lake Balaton, while the usual periods of break-up and ice-off usually take place just in late February and at the end of February, respectively (Fig. 2, Table 2). Based on long-term ice observations, the earliest ice-on was recorded on 20 November 1956, and the latest ice-on was observed on 11 February 1975. The earliest date of freeze-up was on 24 November 1914, while the latest was on 25 February 1902. In the case of break-up, the earliest and latest records were 26 December 1973 and 30 March 1929, respectively. Finally, the earliest date of ice-off was observed on 31 December 1926 and the latest ice-off date was recorded on 8 April 1940. The interannual variability of the dates of the appearance and disappearance of lake ice are 19-22 days in the case of Lake Balaton, which is close to that of the Danube. 


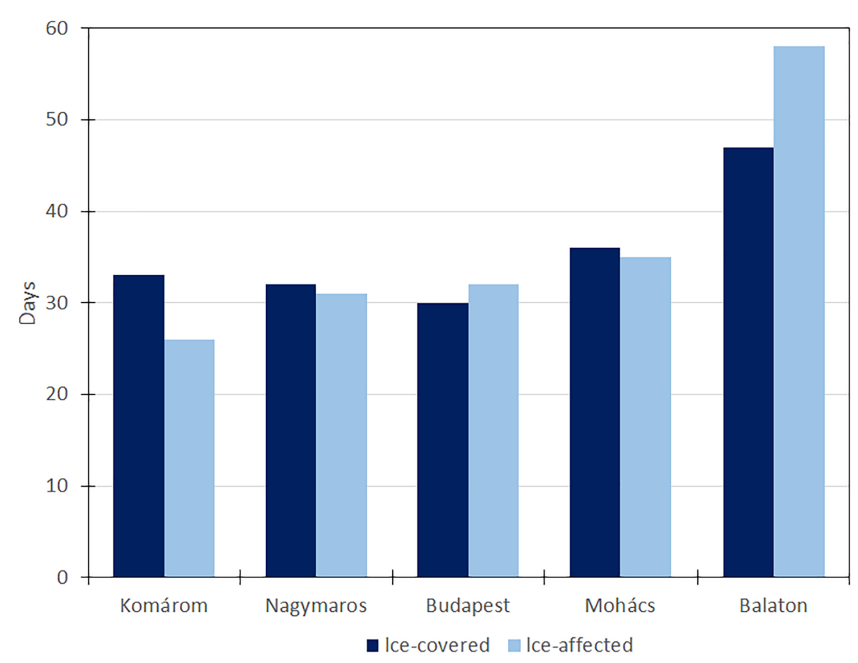

Figure 3. The average length of the ice-covered and ice-affected seasons of the Danube and Lake Balaton: 1885-2017.

The length of the ice-affected season on Lake Balaton excluding the ice-free winters - is 58 days on average, which is 2-3 weeks longer than in the case of the Danube (Fig. 3). The longest ice-affected season was observed in 1962/1963, when 118 days with ice phenomena were recorded. The duration of ice cover is also longer, 47 days on average (discounting winters with no ice cover; Fig. 3). The longest duration of ice cover was observed in 1969/1970, when ice cover remained for 110 days. Compared to the River Danube, ice cover is a more frequent phenomenon on Lake Balaton, with only five winters in which no ice cover developed after ice-on since 1885 . The interannual variability of the ice-covered and ice-affected seasons is 25 and 28 days, respectively, similar to that of the Danube.

\section{Long-term trends in eastern-central European freshwater ice phenology records}

\subsection{The River Danube}

On the basis of the observations, ice-on dates have shifted to a significantly later date over the entire section of the Danube. Similarly, freeze-up dates have also appeared later, but this change was not significant for all stations. In the case of break-up, some differences could be detected: at Komárom and Nagymaros practically no changes could be found, but at Budapest and Mohács break-up has shifted to an earlier point in time, although the trend magnitude was not significant $(p>0.05)$. However, in the last 50 years, ice cover has occurred only once on this river section. Ice-off has also appeared consistently earlier, and in this case the change was significant (Figs. 4 and 5). As a result of later freeze-up and earlier break-up, the duration of ice cover has decreased.

An exception is Komárom, where a slight but not significant increase could be detected. Due to later ice-on and ear- lier ice-off, the ice-affected season was significantly shortened at all sites on the River Danube (Table 4).

The number of ice-free and ice-cover-free winters has increased over the investigated period on the Danube, and especially from the 1970s. Between 1885 and 1965 between 5 and 9 ice-cover-free winters occurred per decade at Komárom and Nagymaros, and 2-7 at Budapest and Mohács, but after 1975 the number of ice-cover-free winters rises to 9-10. Ice-free winters have also become more frequent, again, especially since 1975 .

During the analyzed period anthropogenic interventions have intensified remarkably in the Hungarian section of the Danube and also farther upstream. This also affects the river ice regime, together with the more general phenomena of climate change and increasing winter temperatures (Takács et al., 2013). In the case of the Danube, river regulation works and increasing water pollution have affected the river ice regime. The changes were strongest after the 1960s, when the relative frequency and the duration of ice phenomena and winter air temperatures triggering ice occurrence significantly decreased compared to the previous periods (Takács et al., 2013). Therefore river regulation and pollution, together with increasing temperatures, may well be the cause of the long-term trends in the river ice regime of the Danube River.

\subsection{Lake Balaton}

On the basis of the observations, ice-on (11.56 days $/ 100$ years, $p<0.05)$ and freeze-up (6.56 days/100 years, $p>0.1$ ) have shifted to later dates on Lake Balaton. The magnitude of trend in ice-on was less than half that of the Danube, while in the case of freeze-up, it is about half of that. The date of break-up remains practically unchanged, but ice-off has moved to a significantly earlier timing. The ice-off trend magnitude was also less than half that of the Danube (Fig. 6). The duration of ice cover has not changed, either, with only slight changes in freeze-up and break-up dates. The ice-affected season has shortened as a result of later ice-on and earlier ice-off dates, as on the Danube, but the magnitude of this change was much lower than on the Danube (Table 4).

The frequency of ice-free or ice-cover-free winters has not changed over the analyzed period at Lake Balaton. Compared to the Danube, ice-free winters were very rare at Lake Balaton; only zero to two winters with no ice cover and zero to one winter with no ice have occurred per decade since 1885 .

\subsection{Regional and global outlook}

River ice regime trends relying on an observation period exceeding 100 years have been investigated in the case of some other water bodies in eastern-central Europe (Pawłowski, 2009, 2015; Takács, 2016; Bączyk and Suchożebrski, 2016; Takács and Kern, 2015), providing an opportunity for regional comparison. The investigated trends compared to the 

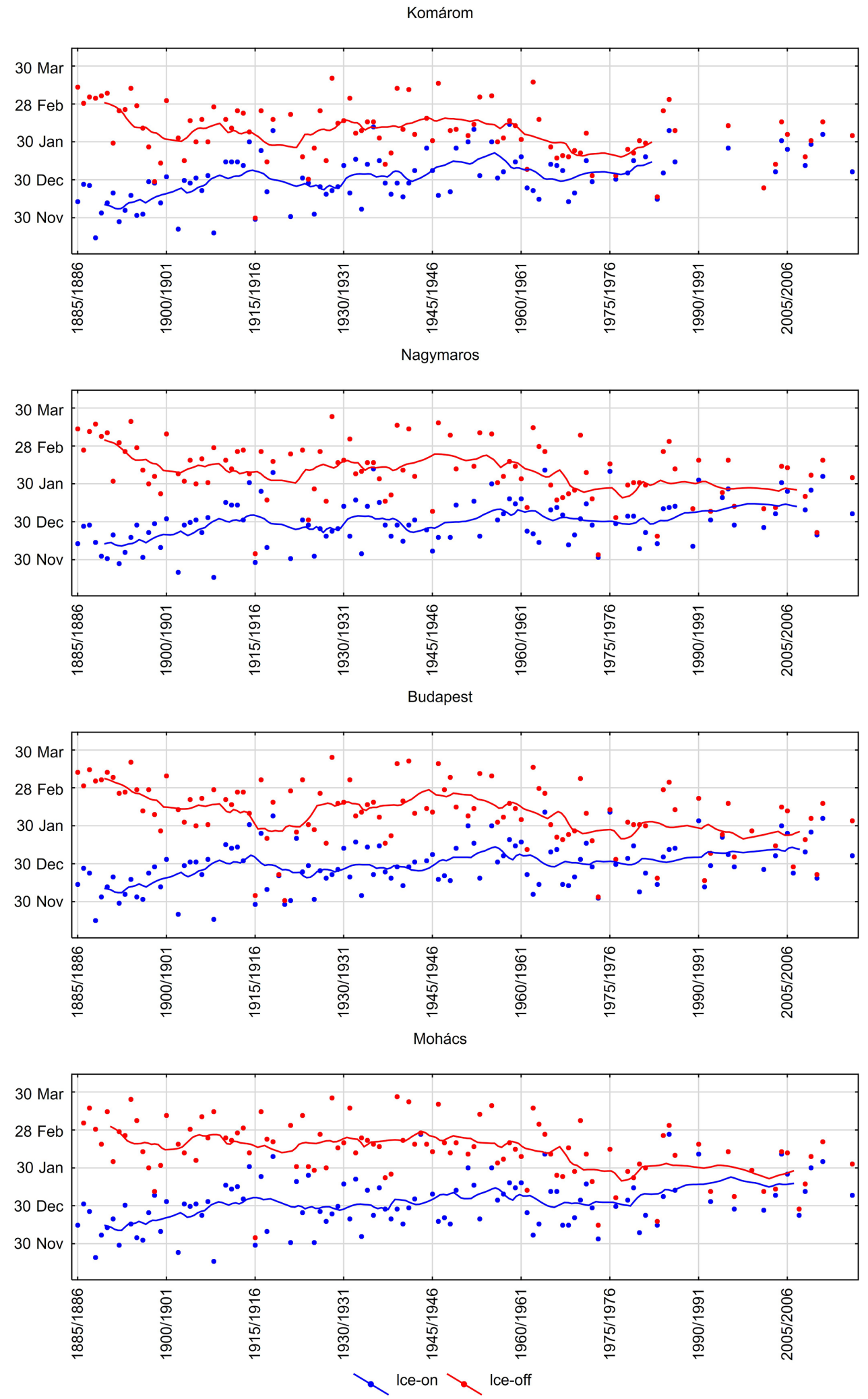

Figure 4. Variations in the dates of ice-on and ice-off on the River Danube from 1885 to 2017. (Blue and red curves are 10-year moving averages.) 

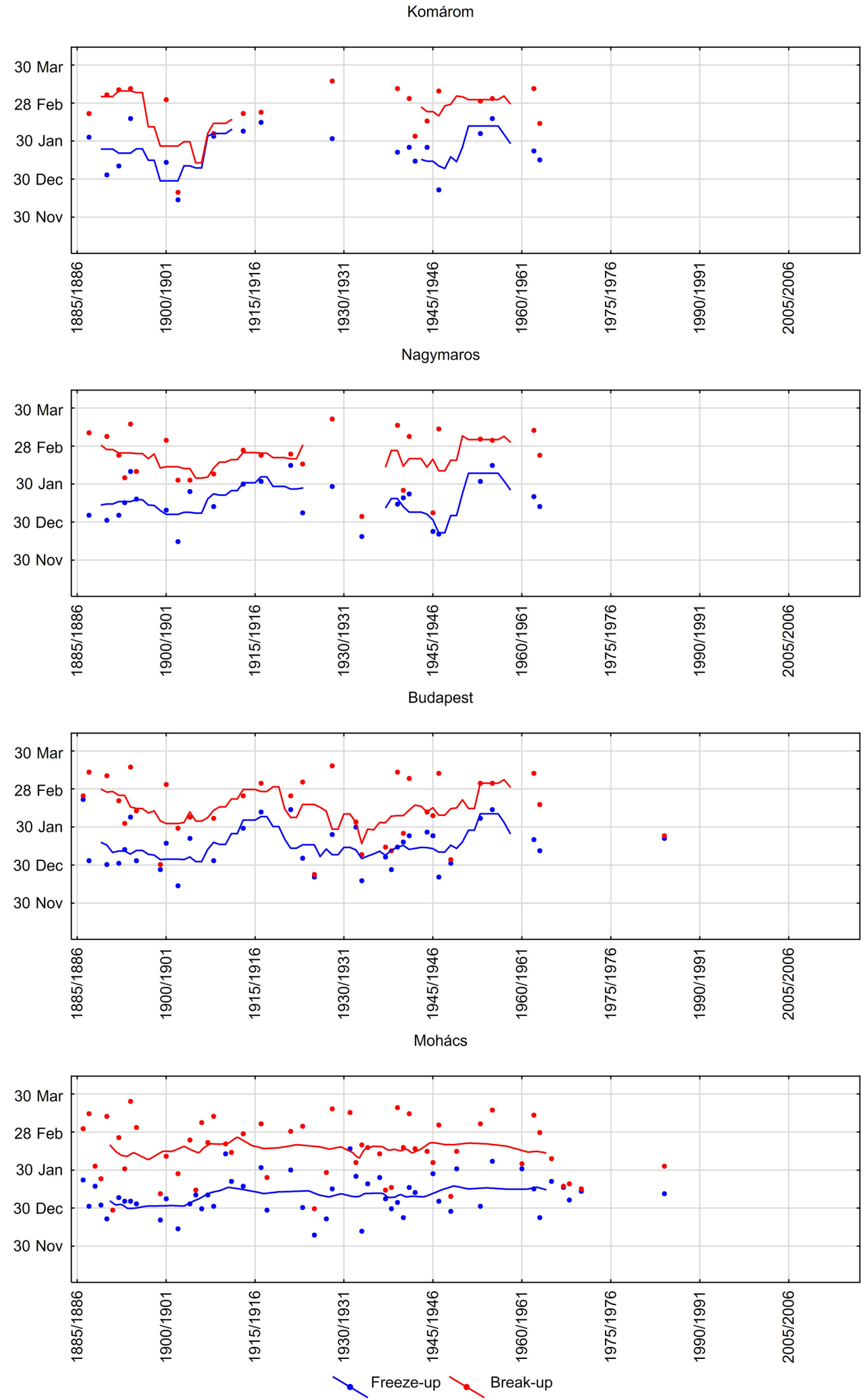

Figure 5. Variations of the date of freeze-up and break-up on the River Danube from 1885 to 2017. (Blue and red curves are 10-year moving averages.) 

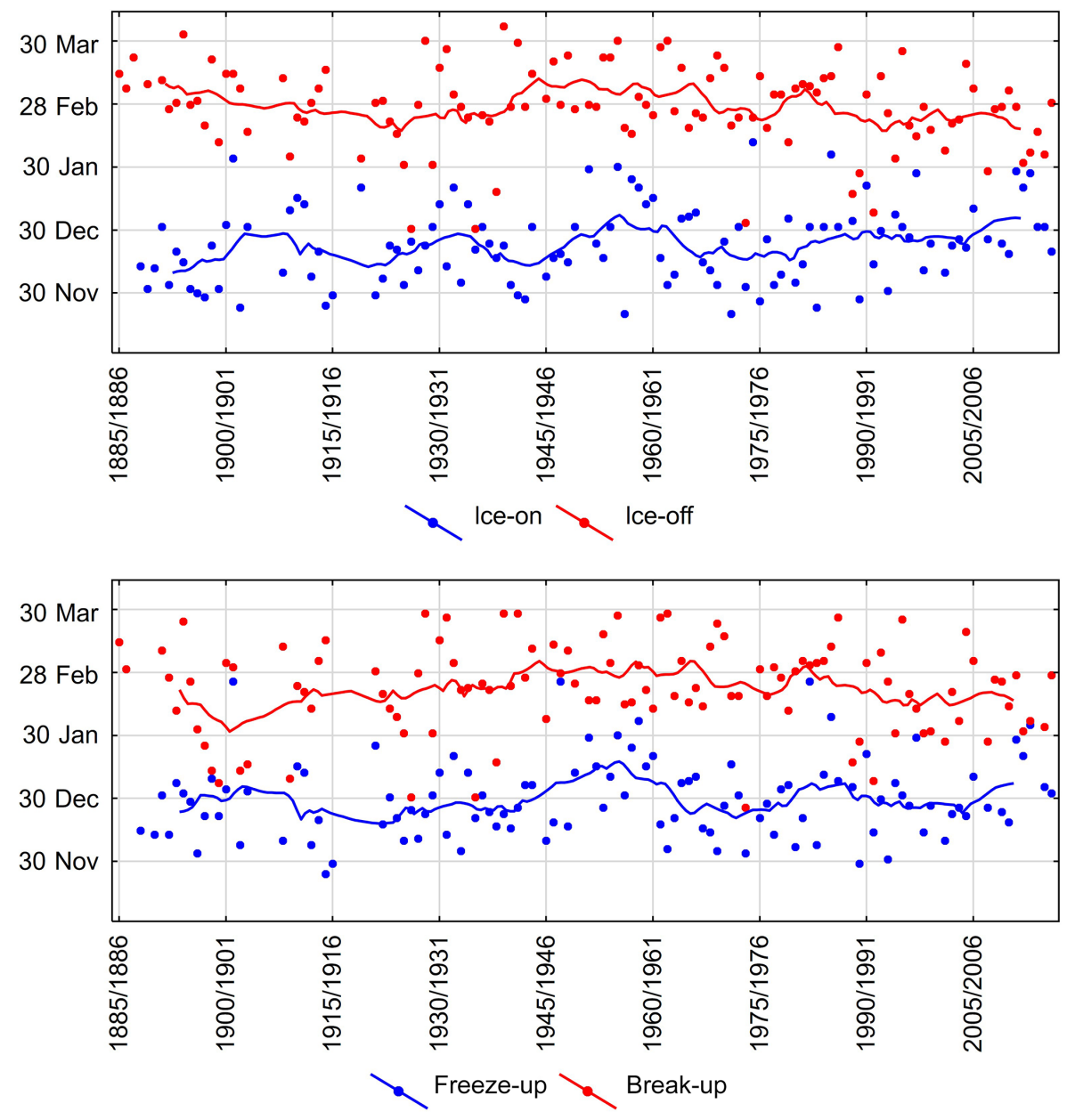

Figure 6. Variations of the dates of ice-on, freeze-up, break-up and ice-off on Lake Balaton from 1885 to 2017. (Blue and red curves are 10-year moving averages.)

trend results of this study display a similar direction, but are of a different magnitude (Table 5). On the Danube, the trend of the ice-on date is similar to the changes detected on the Drava, but much faster than the Raba. Freeze-up dates and ice-off dates on the Danube have changed twice as fast as on the Drava and Raba. The duration of ice cover has decreased to a similar degree on both the Danube and Drava, and somewhat faster than on the Raba. The length of the ice-affected season has also changed most on the Danube. Only in the case of break-up could slower changes on the Danube than on the Drava or Raba be found (Table 5).

Regarding the Lower Vistula, in 1960-2016 the duration of ice phenomena showed a strong decrease ranging from 6.6 to 9.6 days decade $^{-1}$. Duration of ice phenomena was found to be correlated with the pollution of the river water, especially as the (annual mean) concentration of chlorides increased from approx. 40 to $200 \mathrm{mg} \mathrm{dm}^{-3}$ between 1960 and 2014, possibly explaining $\sim 25-30 \%$ of the decrease in ice cover (Pawłowski, 2017). Anthropogenic influences have been observed on ice formation in additional wa- ter bodies, e.g., Silesian Upland (southern Poland) monitored in the winter season of 2009/2010 (Solarski et al., 2011). These observations concur with the reported strengthening of anthropogenic impact on the ice regime of the Danube after the 1960s (Takács et al., 2013) and call for special attention when trends from the late 20th century are to be discussed in a regional context in future studies.

Soja et al. (2014) evaluated the ice regime trends of Lake Balaton over a shorter period (1926-2013) utilizing only the records available from the Central Transdanubian Water Authority, Székesfehérvár, Hungary. The results relating to the trends in ice phenomena were contrary to those observed in the present study: it was found that freeze-up has not changed, break-up has shifted earlier by 7 days/100 years, and the duration of ice cover has decreased by 12 days 100 years (Soja et al., 2014). This discrepancy calls attention to the importance of a common reference period in trend analysis and climate research.

However, long-term freshwater ice phenology data are available mainly for stations outside of eastern-central Eu- 
Table 4. Changes in the ice regime of the River Danube and Lake Balaton from 1885 to 2017. (Values with $p<0.05$ are shown in bold, and $p<0.10$ are given in italics; $R$ : trend calculated by linear regression; MK: trend calculated by a Mann-Kendall test).

\begin{tabular}{lllrrrrr}
\hline (days/100 years) & & Ice-on & Freeze-up & Break-up & Ice-off & Ice cover & Ice-affected \\
\hline Danube River & & & & & & & \\
\hline Komárom & $R$ & $\mathbf{+ 2 8 . 2 8}$ & +4.79 & +1.00 & $\mathbf{- 1 7 . 9 1}$ & +1.18 & $\mathbf{- 2 5 . 7 4}$ \\
& $\mathrm{MK}$ & $\mathbf{+ 3 0 . 3 0}$ & +4.35 & 0.00 & $\mathbf{- 2 1 . 3 0}$ & +1.76 & $\mathbf{- 2 2 . 9 7}$ \\
\hline \multirow{2}{*}{ Nagymaros } & $R$ & $+\mathbf{1 9 . 9 6}$ & +7.62 & +4.06 & $\mathbf{- 2 3 . 1 9}$ & -16.64 & $\mathbf{- 3 4 . 0 6}$ \\
& $\mathrm{MK}$ & $\mathbf{+ 2 1 . 2 5}$ & +14.94 & 0.00 & $\mathbf{- 2 3 . 8 7}$ & -15.79 & $\mathbf{- 3 0 . 6 1}$ \\
\hline Budapest & $R$ & $\mathbf{+ 2 0 . 8 4}$ & +7.35 & -10.65 & $\mathbf{- 2 5 . 6 8}$ & -10.04 & $\mathbf{- 3 3 . 4 8}$ \\
& $\mathrm{MK}$ & $\mathbf{+ 2 1 . 9 8}$ & +12.50 & -7.35 & $\mathbf{- 2 7 . 0 6}$ & -8.16 & $\mathbf{- 2 9 . 2 7}$ \\
\hline \multirow{2}{*}{ Mohács } & $R$ & $\mathbf{+ 2 3 . 8 7}$ & +11.73 & -8.42 & $\mathbf{- 2 5 . 7 2}$ & -15.11 & $\mathbf{- 4 2 . 4 8}$ \\
& $\mathrm{MK}$ & $\mathbf{+ 2 2 . 9 5}$ & +12.14 & -12.50 & $\mathbf{- 2 6 . 1 9}$ & -16.99 & $\mathbf{- 4 1 . 4 0}$ \\
\hline Lake Balaton & & & & & & & \\
\hline Balaton & $R$ & $\mathbf{+ 1 1 . 5 6}$ & +6.56 & +0.67 & -9.04 & -0.73 & -8.56 \\
& $\mathrm{MK}$ & $\mathbf{+ 1 3 . 3 3}$ & +9.09 & 0.00 & $\mathbf{- 9 . 1 8}$ & 0.00 & $\mathbf{- 1 0 . 5 3}$ \\
\hline
\end{tabular}

Table 5. Changes in the ice regime of the rivers Danube, Drava, and Raba. (Values with $p<0.05$ are shown in bold, and $p<0.10$ values are given in italics.)

\begin{tabular}{|c|c|c|c|c|}
\hline (days/100 years) & $\begin{array}{r}\text { Danube, Budapest } \\
(1875-2017) \\
\text { this study }\end{array}$ & $\begin{array}{r}\text { Drava, Barcs } \\
(1875-2014)\end{array}$ & $\begin{array}{r}\text { Raba, Szentgotthárd } \\
(1875-2014) \\
\text { Takács et al. (2013) }\end{array}$ & 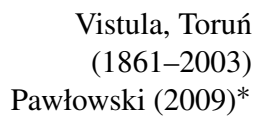 \\
\hline Ice-on & +21.45 & +22.22 & +6.96 & +19 \\
\hline Freeze-up & +10.20 & +4.41 & +5.75 & +13 \\
\hline Break-up & -10.24 & -11.33 & -16.13 & -8 \\
\hline Ice-off & -23.08 & -12.38 & $-\mathbf{1 0 . 0 7}$ & -11 \\
\hline Ice-covered & -14.62 & -9.02 & -14.93 & -39 \\
\hline Ice-affected & -28.24 & -21.92 & -22.41 & -34 \\
\hline
\end{tabular}

* Statistical significance was not published in the original study.

rope (Benson and Magnuson, 2012). A detailed evaluation of the large-scale climatic information that may be hidden in the freshwater ice phenology records of the Danube and Balaton is beyond the scope of this study. Nevertheless, comparison with the longest records from Asia, North America, and Europe highlights the scientific value of these new cryophenological records (Figs. 7 and 8).

For the period of 1774-2017 the changes in freeze-up dates, break-up dates, and duration of ice cover of the Danube were compared to the Red River (Canada-USA), the Angara (Russia), and Tornionjoki (Finland-Sweden). To eliminate the bias of anthropogenic interventions, trend magnitude was calculated for the 1774-1960 period in the case of the Danube. The dates of freeze-up have shifted to later dates in all cases, but on the Danube and Angara the changes were slower than on the Red River. The dates of break-up have shifted to earlier dates except in the case of the Angara River, where later break-up was observed. The magnitude of trend in the Danube is lower compared to the Red and Tornionjoki rivers. The duration of ice cover decreased on the Danube and Red rivers, but on the Angara no significant changes could be detected (Fig. 7).

Freeze-up dates, break-up dates, and the duration of ice cover at Lake Balaton were compared to the corresponding records for Lake Mendota (USA), Lake Baikal (Russia), Lake Suwa (Japan), and Nasijarvi (Finland). In the period 1885-2017 the dates of freeze-up have shifted to a later date at all lakes, but the magnitude of the trend was lower at Lake Balaton than the other lakes. In the case of break-up dates, earlier shifts were observed, but no significant change was detected in the case of Lake Balaton. The duration of ice cover has not changed either at Balaton, but at the other lakes decreasing trends have been detected in both instances (Fig. 8). 

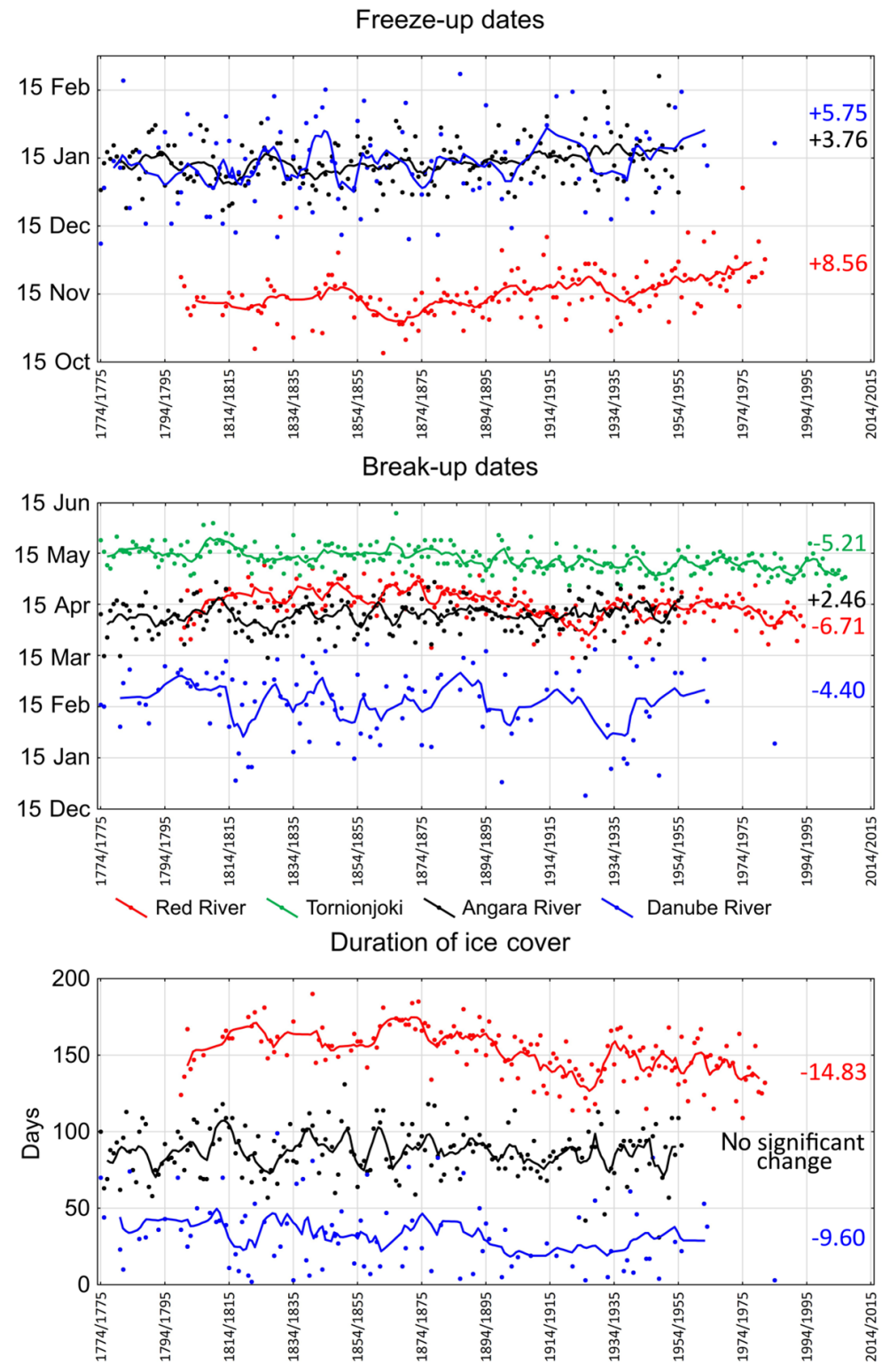

Figure 7. Variations in the dates of freeze-up and break-up on the Red, Tornionjoki, and Angara rivers and the River Danube for 1774-2017. (Data were smoothed using 10-year moving averages. Trend magnitudes are expressed in days/100 years and are marked with the same color.)

\section{Data availability}

The derived dataset is publicly available via PANGAEA at https://doi.org/10.1594/PANGAEA.881056.

\section{Conclusions}

Centennial records of the freshwater ice regime of the largest river (Danube) and the largest lake (Balaton) in easterncentral Europe were compiled. Based on observations covering the period 1885-2017 for the River Danube and Lake Balaton, the freshwater ice regime has significantly changed.
On the Danube the dates of ice-on and freeze-up have shifted to later dates by $21-30$ and $4-15$ days/100 years, respectively, while on Lake Balaton these changes were only 13 and 9 days/100 years. Break-up dates and ice-off dates have shifted earlier by 7-13 and 21-27 days/100 years on the Danube, but at Balaton the date of break-up has not changed significantly, while ice-off has moved later by only 9 days/100 years. The changes in the dates of ice phenomena have resulted in a shortening of both the ice-covered and ice-affected periods. The duration of the ice-affected season has decreased on both water bodies by 23-41 days/100 years on the Danube and 11 days/100 years on Balaton. The du- 

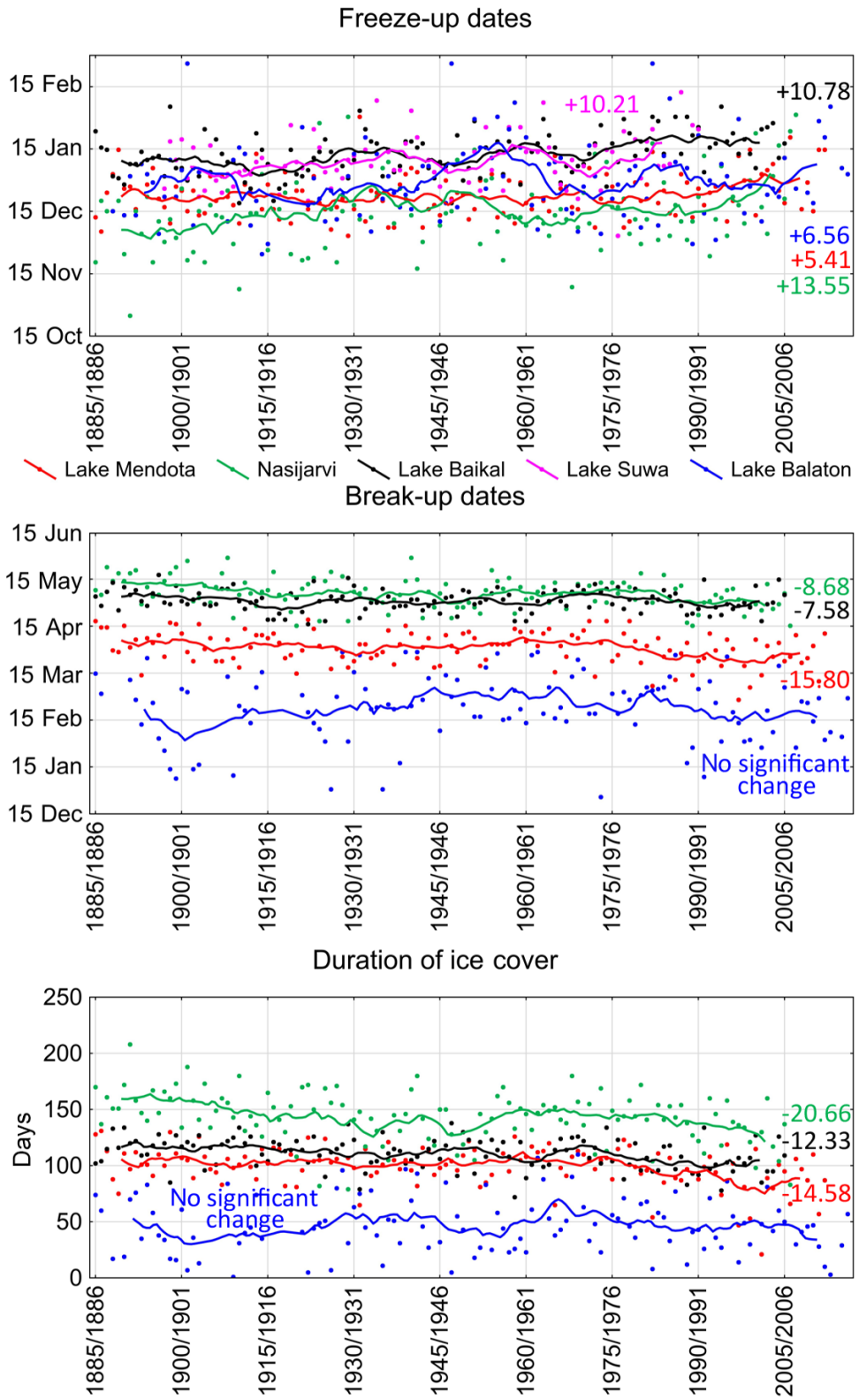

Figure 8. Variations in the dates of freeze-up and break-up on lakes Mendota, Näsijärvi, Baikal, Suwa, and Balaton from 1885 to 2017. (Data were smoothed using 10-year moving averages. Trend magnitudes are expressed in days/100 years and are marked with the same color.)

ration of ice cover has decreased by $8-17$ days/100 years on the Danube, while on Lake Balaton no significant changes could be detected. Comparing on regional and global scales, the detected temporal trends in freshwater ice regimes are congruent with the changes in other water bodies for which long-term time series of ice phenology records are available. The changes are in the same direction, but of different magnitude.

These long-term time series of freshwater ice have a potential resource for (paleo)climatological research due to the strong, physically deterministic link between water and air temperature and freshwater ice phenomena. The com- piled cryophenological records for eastern-central Europe are readily available for detailed analysis of the temporal trends, large-scale spatial comparison, or other climatological research purposes.

Author contributions. KT collected the data and performed the statistical analyses. KT and ZK interpreted the results with contributions from LP. KT and ZK drafted the manuscript, which was further improved with contributions from LP. 
Competing interests. The authors declare that they have no conflict of interest.

Acknowledgements. This is contribution no. 53 of the $2 \mathrm{ka}$ Palaeoclimatology Research Group.

Edited by: Reinhard Drews

Reviewed by: Corinna Gries and Boguslaw Pawlowski

\section{References}

Arenstein, J.: Beobachtungen über die Eisverhältnisse der Donau: $1847 / 48$ bis $1849 / 50$ [Ice regime observations of the Danube River: from $1847 / 48$ to $1849 / 50]$, Vienna, Austria, 1850.

Assel, R. A. and Herche, L. R.: Ice-on, ice-off, and ice duration for lakes and rivers with long-term records, in: Ice in surface waters: Proceedings of the 14th international symposium on ice, edited by: H. T. Shen, New York, USA, 27-31 July 1998, vol. 1, 147$151,1998$.

Bączyk, A. and Suchożebrski, J.: Variability Of Ice Phenomena On The Bug River (1903-2012), Ecol. Eng., 49, 136-142, https://doi.org/10.12912/23920629/64511, 2016.

Baranyi, S.: A Balaton hidrológiai jellemzői [Hydrological characteristics of the Lake Balaton], Vízügyi Közlemények, 57, 249262, 1975.

Barry, R. and Gan, T. Y.: Freshwater ice, in The global cryosphere, Past, present and future, Cambridge University Press, Cambridge, UK, 190-218, 2011.

Beltaos, S. and Prowse, T.: River-ice hydrology in a shrinking cryosphere, Hydrol. Process., 23, 122-144, https://doi.org/10.1002/hyp.7165, 2009.

Benson, B. J. and Magnuson, J. J.: Global Lake and River Ice Phenology Database, Version 1, updated NSIDC (National Snow and Ice Data Center), Boulder, Colorado, USA, 2012.

Brooks, R. N., Prowse, T. D., and O'Connell, I. J.: Quantifying Northern hemisphere freshwater ice, Geophys. Res. Lett., 40, 1128-1131, https://doi.org/10.1002/grl.50238, 2013.

Carlson, R. F.: Ice Formation on Rivers and Lakes, North. Eng., 13, 4-9, 1981.

Cholnoky, J.: A Balaton jege [The ice of the Lake Balaton], in: A Balaton tudományos tanulmányozásának eredményei I, A Balaton környékének fizikai földrajza, A Balaton vizének fizikai tulajdonságai, Magyar Földrajzi Társaság Balaton Bizottsága, Budapest, p. 104, 1907.

Fritsch, K.: Die Eisverhältnisse der Donau in Österreich ob und unter der Enns und Ungarn in den Jahren 1851/52 bis 1860/61 [The ice regime of Danube River in Austria upstream and downstream to Enns and in Hungary from 1851/52 to 1860/61], in: Denkschriften der mathematisch naturwissenschaftlichen Classe der kaiserlichen Akademie der Wissenschaften Wien, Wien, 121-244, 1864.

Fritsch, K.: Die Eisverhältnisse der Donau in den beiden Jahren 1860/1 bis 1861/2 [The ice regime of Danube River in 1860/1 and 1861/2], in: Denkschriften der mathematisch naturwissenschaftlichen Classe der kaiserlichen Akademie der Wissenschaften Wien, Wien, 432-479, 1867.
Fujiwhara, S.: Notes on the climatic variations concluded from the dates of the first complete freezing of Lake Suwa in Japan, Geogr. Ann., 3, 358-361, https://doi.org/10.2307/519448, 1921

Gray, B. M.: Early Japanese winter temperatures, Weather, 29, 103 107, https://doi.org/10.1002/j.1477-8696.1974.tb04348.x, 1974.

Groveman, S. and Landsberg, H. E.: Simulated Northern Hemisphere temperature departures 1579-1880, Geophys. Res. Lett., 6, 767-769, https://doi.org/10.1029/GL006i010p00767, 1979.

Herman, O.: A magyar halászat könyve [The book of fishing in Hungary], Királyi Magyar Természettudományi Társulat, Budapest, 1887.

Hicks, F.: An overview of river ice problems: CRIPE07 guest editorial, Cold Reg. Sci. Technol., 55, 175-185, https://doi.org/10.1016/j.coldregions.2008.09.006, 2009.

Jensen, O. P., Benson, B. J., Magnuson, J. J., Card, V. M., Futter, M. N., Soranno, P. A., and Stewart, K. M.: Spatial analysis of ice phenology trends across the Laurentian Great Lakes region during a recent warming period, Limnol. Oceanogr., 52, 20132026, https://doi.org/10.4319/lo.2007.52.5.2013, 2007.

Kendall, M. G.: Rank correlation methods, 4th edn., Charles Griffin, London, UK, 272 pp., 1975.

Klausz, A. and Pászthory, R.: A Magyar Hidrológiai Adatbázis megvalósulása [The implementation of the Hungarian Hydrological Database], in: L A Magyar Hidrológiai Társaság XIX, Országos Vándorgyúlése II, kötet, 701-705, 2001.

Klavins, M., Briede, A., and Rodinov, V.: Long term changes in ice and discharge regime of rivers in the Baltic region in relation to climatic variability, Clim. Change, 95, 485-498, https://doi.org/10.1007/s10584-009-9567-5, 2009.

Kuzmann, G.: Hidrológiai észlelések a Duna budapesti szelvényében [Hydrological observations on the River Danube at Budapest 1817-1875], Hidrológiai Közlöny, 61, 358-368, 1981.

Lászlóffy, W.: A folyók jégviszonyai, különös tekintettel a magyar Dunára [Ice regime of rivers, in particular the River Danube], Vízügyi Közlemények, 16, 369-435, 1934.

Leppäranta, M.: Modelling the Formation and Decay of Lake Ice, in: The Impact of Climate Change on European Lakes, edited by: George, G., Springer Science + Business Media B.V., Dordrecht, 63-83, 2010.

Liljequist, G.: Winter temperatures and ice conditions of Lake Vetter with special regard to the winter 1939/40, Geogr. Ann., 23, 24-52, https://doi.org/10.2307/519933, 1941.

Lind, L., Nilsson, C., Polvi, L. E., and Weber, C.: The role of ice dynamics in shaping vegetation in flowing waters, Biol. Rev., 89, 791-804, https://doi.org/10.1111/brv.12077, 2014.

Lukács, K.: Jégi halászat a Balatonon [Fishing on the ice of the Lake Balaton], Halászat, 35, 14-41, 1934.

Magnuson, J. J., Robertson, D. M., Benson, B. J., Wynne, R. H., Livingstone, D. M., Arai, T., Assel, R. A., Barry, R. G., Card, V., Kuusisto, E., Granin, N. G., and Prowse, T. D.: Historical Trends in Lake and River Ice Cover in the Northern Hemisphere, Science, 289, 1743-1746, https://doi.org/10.1126/science.289.5485.1743, 1999.

Mann, H. B.: Nonparametric Tests Against Trend, Econometrica, 13, 245-259, 1945.

Pawłowski, B.: Long-Term variability in the course of ice phenomena on the Vistula River in Torun, Bulletin of Geography - Physical Geography Series, 1, 91-102, 2009. 
Pawłowski, B.: Determinants of change in the duration of ice phenomena on the Vistula River in Torun, J. Hydrol. Hydromech., 63, 145-153, https://doi.org/10.1515/johh-2015-0017, 2015.

Pawlowski, B.: Przebieg zjawisk lodowych dolnej Wisły w latach 1960-2014, Wydawnictwo Naukowe Uniwersytetu Mikołaja Kopernika, 2017.

Prowse, T. D., Wrona, F. J., Reist, J. D., Gibson, J. J., Hobbie, J. E., Lévesque, L. M. J., and Vincent, W. F.: Climate change effects on hydroecology of arctic freshwater ecosystems., Ambio, 35, 347-358, https://doi.org/10.1579/0044-7447(2006)35, 2006.

Prowse, T. D., Bonsal, B. P., Duguay, C. R., Hessen, D. O., and Vuglinsky, V. S.: River and Lake Ice, in Global Outlook for Ice and Snow, UNEP, 201-214, 2007a.

Prowse, T. D., Bonsal, B. R., Duguay, C. R., and Lacroix, M. P.: River-ice break-up/freeze-up: A review of climatic drivers, historical trends and future predictions, Ann. Glaciol., 46, 443-451, https://doi.org/10.3189/172756407782871431, 2007b.

Rácz, L.: The Danube Pontoon Bridge of Pest-Buda (17671849) as an Indicator and Victim of the Climate Change of the Little Ice Age, Glob. Environ., 9, 458-493, https://doi.org/10.3197/ge.2016.090207, 2016.

Réthly, A.: Időjárási események és elemi csapások Magyarországon 1701-1800 [Weather events and natural disasters in Hungary 1701-1800], Akadémiai Kiadó, Budapest, 1970.

Réthly, A. and Simon, A.: Időjárási események és elemi csapások Magyarországon 1801-1900. I. kötet [Weather events and natural disasters in Hungary 1801-1900], vol. 1, OMSz, Budapest., 1998.

Réthly, A. and Simon, A.: Időjárási események és elemi csapások Magyarországon 1801-1900. II. kötet [Weather events and natural disasters in Hungary 1801-1900], vol. 2, OMSz, Budapest., 1999.

Sáringer, J. K.: A tó hőmérsékleti viszonyai [The thermal regime of the Lake Balaton], in: A Balaton tudományos tanulmányozásának eredményei I. A Balaton környékének fizikai földrajza. A Balaton vizének fizikai tulajdonságai, Magyar Földrajzi Társaság Balaton Bizottsága, Budapest, p. 52, 1900.

Sen, P. K.: Estimates of the Regression Coefficient Based on Kendall's Tau, J. Am. Stat. Assoc., 63, 1379-1389, 1968.

Sharma, S., Magnuson, J. J., Batt, R. D., Winslow, L. A., Korhonen, J., and Aono, Y.: Direct observations of ice seasonality reveal changes in climate over the past 320-570 years, Sci. Rep.-UK, 6, 25061, https://doi.org/10.1038/srep25061, 2016.

Smith, L. C.: Trends in Russian Arctic river-ice formation and breakup, 1917 to 1994, Phys. Geogr., 21, 46-56, 2000.

Soja, A. M., Kutics, K., Maracek, K., Molnár, G., and Soja, G.: Changes in ice phenology characteristics of two Central European steppe lakes from 1926 to 2012 - influences of local weather and large scale oscillation patterns, Clim. Change, 126, 119-133, https://doi.org/10.1007/s10584-014-1199-8, 2014.
Solarski, M., Pradela, A., and Rzetala, M.: Natural and anthropogenic influences on ice formation on various water bodies of the Silesian Upland (southern Poland), Limnol. Rev., 11, 33-44, https://doi.org/10.2478/v10194-011-0025-1, 2011.

Starosolszky, Ö.: A Balaton jege [The ice of the Lake Balaton], Hidrológiai Közlöny, 68, 173-181, 1988.

Takács, K.: Klimatikus, hidrológiai és antropogén hatésok értelemzése folyó- és állóvizeink jégviszonyainak évszázados változásában [Interpretation of climatic, hydrological and anthropogenic impacts on the multidecadal changes of river and lake ice regime in the Car], Eötvös Loránd Tudományegyetem, Budapest, 2016.

Takács, K. and Kern, Z.: Multidecadal changes in the river ice regime of the lower course of the River Drava since AD 1875, J. Hydrol., 529, 1890-1900, https://doi.org/10.1016/j.jhydrol.2015.01.040, 2015.

Takács, K., Kern, Z., and Nagy, B.: Impacts of anthropogenic effects on river ice regime: Examples from Eastern Central Europe, Quat. Int., 293, 275-282, https://doi.org/10.1016/j.quaint.2012.12.010, 2013.

Takács, K. and Kern, Z.: Long-term ice phenology records of Lake Balaton and the Danube River (East Central Europe), PANGAEA, https://doi.org/10.1594/PANGAEA.881056, 2017

Vadas, A.: "A Dunára én bizon nem megyek, mert még nem akarok meghalnom": A Duna jégjelenségei a kora újkorban (15301650) [I Am Not Going on the Danube's Ice since I Don't Want to Die": The Ice-Regime of Danube in the Early Modern Times (1530-1650)], in: MICAE MEDIAEVALES III - Fiatal történészek dolgozatai a középkori Magyarországról és Európáról, edited by: Gál, J., Péterfi, B., Vadas, A., and Kranzieritz, K., ELTE BTK Történelemtudományok Doktori Iskola, Budapest, 219-235, 2013.

VITUKI: Adatgyưjtemény folyóink jégviszonyairól [Data collection of the ice regime of our rivers], VITUKI, Budapest, 1974.

Weyhenmeyer, G. A., Livingstone, D. M., Meili, M., Jensen, O., Benson, B., and Magnuson, J. J.: Large geographical differences in the sensitivity of ice-covered lakes and rivers in the Northern Hemisphere to temperature changes, Glob. Chang. Biol., 17, 268-275, https://doi.org/10.1111/j.1365-2486.2010.02249.x, 2011.

Williams, G. P.: A note on the break-up of lakes and rivers as indicators of climate change, Atmosphere, 8, 23-24, 1970. 